\title{
Correction to: Trastuzumab-induced upregulation of a protein set in extracellular vesicles emitted by ErbB2- positive breast cancer cells correlates with their trastuzumab sensitivity
}

Arik Drucker ${ }^{1}$, Byong Hoon Yoo ${ }^{2}$, Iman Aftab Khan ${ }^{2}$, Dongsic Choi ${ }^{3}$, Laura Montermini ${ }^{3}$, Xiaoyang Liu ${ }^{2}$, Sanja Jovanovic ${ }^{1}$, Tallal Younis ${ }^{1}$ and Kirill V. Rosen ${ }^{2,4^{*}}$

Correction to: Breast Cancer Res 22, 105 (2020) https://doi.org/10.1186/s13058-020-01342-2

Following publication of the original article [1], the authors identified an error in the author name of Arik Drucker.

The incorrect author name is: Arik Durcker.

The correct author name is: Arik Drucker.

The author group has been updated above and the original article [1] has been corrected.

\section{Author details}

'Department of Medicine, Dalhousie University, Halifax, NS, Canada. ${ }^{2}$ Departments of Pediatrics \& Biochemistry and Molecular Biology, Dalhousie University, Halifax, NS, Canada. ${ }^{3}$ Research Institute of the McGill University Health Centre, Glen Site, McGill University, Montreal, QC, Canada. ${ }^{4}$ Atlantic Research Centre, Rm C-304, CRC, 5849 University Avenue, PO Box 15000, Halifax, NS B3H 4R2, Canada.

Published online: 22 October 2020

\section{Reference}

1. Durcker, et al. Breast Cancer Res. 2020;22:105 https://doi.org/10.1186/

s13058-020-01342-2.

The original article can be found online at https://doi.org/10.1186/s13058020-01342-2.

* Correspondence: kirill.rosen@dal.ca

${ }^{2}$ Departments of Pediatrics \& Biochemistry and Molecular Biology, Dalhousie University, Halifax, NS, Canada

${ }^{4}$ Atlantic Research Centre, Rm C-304, CRC, 5849 University Avenue, PO Box 15000, Halifax, NS B3H 4R2, Canada

Full list of author information is available at the end of the article

(c) The Author(s). 2020 Open Access This article is licensed under a Creative Commons Attribution 4.0 International License, which permits use, sharing, adaptation, distribution and reproduction in any medium or format, as long as you give appropriate credit to the original author(s) and the source, provide a link to the Creative Commons licence, and indicate if changes were made. The images or other third party material in this article are included in the article's Creative Commons licence, unless indicated otherwise in a credit line to the material. If material is not included in the article's Creative Commons licence and your intended use is not permitted by statutory regulation or exceeds the permitted use, you will need to obtain permission directly from the copyright holder. To view a copy of this licence, visit http://creativecommons.org/licenses/by/4.0/ The Creative Commons Public Domain Dedication waiver (http://creativecommons.org/publicdomain/zero/1.0/) applies to the data made available in this article, unless otherwise stated in a credit line to the data. 